\title{
THE THOUGHT IN JOHN 1:3c-4
}

\author{
John Nolland
}

\begin{abstract}
Summary
With a working assumption that the final words of verse 3 belong with verse 4 , the article seeks to clarify the thought in the three clauses making up verses $3 c-4$. It concludes that the thought expressed is this: the mystery of animate life, existing as it does 'in the Logos', shines as a light upon humanity, a light intended to light up the divine presence in the world in that it reveals the presence and working of the Logos. A second alternative is possibly viable: creation is life-giving, and the life it gives acts as a light revealing the Logos.
\end{abstract}

\section{Introduction}

There is not a scholarly consensus on whether ô rérovev ('what has come to be') at the end of John 1:3 belongs with the material before in verse 3 , or with the material to come in verse 4 . The claim has been made that most recent scholarship has favoured the latter. ${ }^{1}$ There is, however, still spirited defence of the former view. ${ }^{2}$ I side with the

1 G. R. Beasley-Murray, John (2nd edn; Nashville: Thomas Nelson, 1999): 2, claims the majority for this view. P. M. Phillips, The Prologue of the Fourth Gospel: A Sequential Reading (LNTS 294; London: T\&T Clark, 2006): 162 n. 92, provides a good list of supporters of the two views, and argues for the 'majority' view. M. Endo, Creation and Christology: A Study on the Johannine Prologue in the Light of Early Jewish Creation Accounts (WUNT 2/149; Tubingen: Mohr Siebeck, 2002): 196 n. 55, should be added to his list of supporters of the 'minority' view, and J. LeonhardtBalzer, 'Der Logos und die Schöpfung: Streiflichter bei Philo (Op 20-25) und im Johannesprolog (Joh 1,1-18)' in Kontexte des Johannesevangeliums: das vierte Evangelium in religions- und traditionsgeschichtlicher Perspektive, ed. J. Frey, U. Schnelle and J. Schlegel (WUNT 2/175; Tübingen: Mohr Siebeck, 2004): 295-319 (esp. 314); M. Hengel, 'The Prologue of the Gospel of John as the Gateway to Christological Truth' in The Gospel of John and Christian Theology, ed. R. Bauckham and C. Mosser (Grand Rapids: Eerdmans, 2008): 265-94, to the 'majority' view.

2 See e.g. D. A. Carson, The Gospel according to John (Leicester; Inter-Varsity, 1991): 13-38, 118, who appeals to the more detailed argumentation of 
scholars who favour the latter. An adequate discussion of the issues involved here lies outside the scope of the present paper, though I do appreciate that for those who think ö Yé Yovev belongs with verse 3 the presentation offered here is a non-starter. With a working assumption that ö Y'́YOvev belongs with verse 4, the concern here is with seeking to clarify the thought in the three clauses making up verses $3 \mathrm{c}-4$. When the argument has been made that ô Y'́r Yovev belongs with verse 4, strong as it seems to be on other fronts, there has not been, I believe, sufficient attention given to the precise sense of the set of linked clauses in verses $3 \mathrm{c}-4$ that result. The possibility of identifying a satisfactory sense offers itself as, among other things, a test of the working assumption about punctuation. (I hasten to add that this in no way claims to demonstrate the working assumption; the main weight of the case for linking the final clause of v. 3 with v. 4 must remain elsewhere, and outside the scope of this essay.)

A first observation to make is that, though things will be different later in the prologue, 'the light' in verse 5 is not a freestanding entity, but rather a way in which 'the life' spoken of in verse $4 \mathrm{~b}$ functions. In turn, 'the life' picks up on the use of 'life' in the previous difficult clause. Where are we to locate the 'life' of verse $4 a$, out of which this sequence flows? The thought of verses $3 c-4$ is largely determined by the answer to this question.

Although my working assumption is that ò Y'́rovev ('which/what has come [to be]') belongs with verse 4 , it is the alternative view that gives an immediately clear answer to the question of where the life is: it is in the Logos. How this life then becomes the light for all people, however, remains unclear with this punctuation, and something of a disjunction opens up between verses 3 and 4 . Let me clarify.

Verses 1-2 identify the primal state of affairs: the Logos is introduced and his connection with God specified in verse 1 and the unit is rounded off in verse 2 with a summary that repeats in a more compact form the material of the opening two clauses. (The content of the third clause is not repeated, but it gains its own emphasis by sitting between the initial statements made in the first two clauses and their

R. Schnackenburg, The Gospel according to St John (New York: Crossroads, 1981): 1:239-40. The most careful recent defence of this view is that of H. Thyen, Studien zum Corpus Iohanneum (WUNT 214; Mohr Siebeck, 2007): 411-17. Most recently J. F. McHugh, John 1-4 (ICC; London: T\&T Clark, 2009): 14-15, 104-107, leans in the same direction, but without definite resolution of the question. 
repetition in v. 2.) Verse 3 then moves on from the primal state to the coming into existence of creation; and the forming of creation is said to have taken place by means of the Logos. ${ }^{3}$ The second clause of verse 4 continues on this track: the life that was in the Logos acts as a light for the people of the created order. The sequence is: primal state, forming of the created order, what happens in the created order. But life as in the Logos was not a point that was made about the Logos in relation to the primal state of affairs in verses 1-2. The opening clause of verse 4, therefore, has to be given to introducing fresh information about the Logos. The clause, in effect, backs up to tell us something further about how it was with the Logos (presumably from the beginning) before the verse can go on to make its point about how the Logos, or more exactly something about the Logos, functioned in relation to the created order, or at least the people of the created order: the 'lifefulness' of the Logos was the light of humanity-whatever this might mean and however the light is supposed to have been accessed. ${ }^{4}$

One can hardly call this a poetic fatal flaw, but all things being equal a way of reading the materials that allowed for a clean movement from the primal state to the act of creation and then to what happens in creation would be preferable. ${ }^{5}$

On the other hand, taken as linked with verse 4 , ò Yérovev takes up the new development in verse 3 (creation) which has moved us on from the original beginning point, and deals with an aspect of how things were as a result. ${ }^{6}$ So it clearly handles the sequencing better. An

3 I follow the overwhelming scholarly consensus that John 1:3 is about the creation of the world. P. Lamarche, 'The Prologue of John' in The Interpretation of John, ed. J. Ashton (2nd edn; Edinburgh: T\&T Clark, 1997): 47-65 (French original, 1964), has argued that rivoual should be translated as 'happen' and that v. 3 is about the realisation of the divine plan. T. E. Pollard, 'Cosmology and the Prologue of the Fourth Gospel', Vigiliae Christianae 1 (1958): 147-53 before him also argued for v. 3's being about the realisation of the divine plan, and not creation as such. A full engagement with Lamarche is not possible here, but may it suffice to make two points. 1) Lamarche requires vv. 4-5 to refer to 'the accomplishment of salvation' (56), but this leaves vv. 6-9 rather hanging. 2) While 'everything happened through him' works quite well for v. 3, 'the world happened through him' is not very natural for v. 10 .

4 No doubt John 1:9 would be important for any clarification here.

5 A move from primal state to creation (John 1:1-2 to v. 3) and then a second move from primal state to creation (v. 4a to v. 4b) would have been structurally better represented with a further use of É Ýंveto (picking up on those in v. 3) in place of the second $\tilde{\eta} v$ in John 1:4.

6 The proposal of E. L. Miller ('The Logic of the Logos Hymn: A New View', NTS 29 [1983]: 552-61; Salvation History in the Prologue of John: The Significance of John 
extra bonus here is that it allows structure to be marked by verb choices: a first set of uses of $\tilde{\eta} v$ mark what was the original state of affairs (vv. 1-2); the uses of Yívoual mark transition to a new state of affairs (creation takes place; v. 3); a second set of uses of $\tilde{\eta} v$ comment on aspects of how things were within this new state of affairs (vv. 4-5).

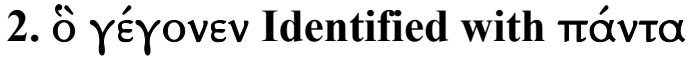

Exactly what is to be understood as taken up depends upon how important parts of the syntax are to be construed. It is normally considered that 'what came to be' is identical to 'all things' of verse 3 . This fits the widely recognised tendency in the prologue for abbreviated restatement to precede fresh development (as already in v. 2). We will initially look at options that involve treating 'what came to be' as identical with 'all things'. But the situation may not be so simple and we will need to come back to this matter.

\section{1 ö Yérovevas Pendant Nominative}

Most scholars who link ô YéYovev with verse 4 also consider it to be the subject of $\tilde{\eta} v$, but Bultmann among others has insisted that it be taken as a pendant nominative. ${ }^{7}$ The choice here must be considered in relation to the other elements of the sentence.

What is the situation if we take ö rérovev as a pendant nominative? The brokenness of syntax involved in a pendant nominative inevitably leaves more to be construed by the reader and therefore makes it harder to be sure what is intended. Bultmann offered two alternatives: "what has come to be-in him (the Logos) was the life (for it)'; or 'what has come to be-in it he (the Logos) was the life'. ${ }^{8}$ In

1:3, 4 [NovTSup 60; Leiden: Brill, 1989]) that there is a reference at this point to the Incarnation has not been followed by other scholars.

7 R. Bultmann, The Gospel of John: A Commentary (Philadelphia: Westminster, 1971): 39. This represents a change of opinion from 'The History of Religions Background of the Prologue to the Gospel of John' in The Interpretation of John, 2746 (German original, 1923), ed. J. Ashton. At that point he was still of the view that the final clause of John 1:3 belonged with v. 3 (but was an interpretive gloss, designed to rule out what was, as it turns out, an impossible misunderstanding).

8 A. Dettwiler, 'Le prologue johannique (Jean 1,1-18)', Communauté johannique et son histoire: La trajectoire de l'Évangile de Jean au deux premiers siècles, ed. J.-D. Kaestli, J. M. Poffet and J. Zumstein (Geneva: Labor et Fides, 1990): 185-203 (esp. 197), includes this in his list of options, but is not finally persuaded. K. Aland, 'Eine 
both the central thought is that the Logos is the source of life, a thought that fits well within the Gospel more broadly. But for the former we would have expected an article with $\zeta \omega$ ('life'), and might have expected a pronoun or a pronoun phrase for 'for it'. In the latter it is

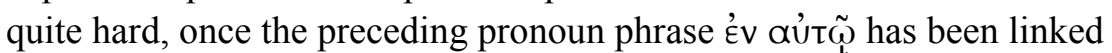
to the created order and not to the Logos-breaking the chain of pronouns used of the Logos in verse 3-to take o $\lambda$ óros as the (unexpressed) subject of $\tilde{\eta} v,{ }^{9}$ and again we might have expected an article with $\zeta \omega \eta$. Apart from the fact that both options express a thought that would fit well, there is little to commend Bultmann's proposals. ${ }^{10}$ It is unlikely that the syntax should be construed in either of these ways. Nonetheless the concern to see the Logos as the source of life is surely a right impulse in a Johannine frame of thought.

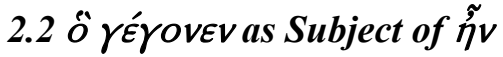

So we set Bultmann's proposals to one side and turn to a consideration

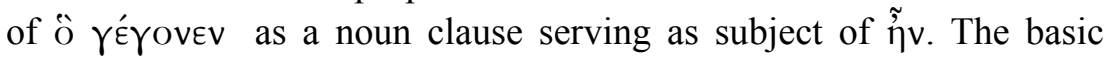
shape of the sentence is now 'what has come to be was life', whatever that might mean. 'Was life' will become the focus of our attention a little later.

We consider first the possibility that $\mathcal{E} v$ aủ $\tilde{\omega}$ is to be linked with ô

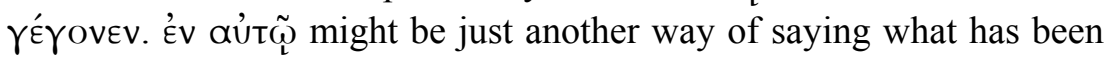
expressed with $\delta$ ' ' aútoũ ('through him') in verse 3 . This would give three parallel ways of expressing the agency of the Logos in creation: $\delta$ ' aưtoũ '[everything] through him') and $\chi \omega$ wis aưtoũ ('[nothing] apart from him') in verse 3 and now Év aút ஸि ('[what has come to be] in connection with him') in verse 4 . This is an immediately attractive option, given John's obvious tendency to say the same things in different ways.

The other possibility is that the thought might be locative in some sense. It might then mean that some connection with the Logos is involved in the creation order getting and therefore keeping its lifethe ongoing existence of the created order is being seen as 'in the

Untersuchung zu Johannes 1, 3-4. Über die Bedeutung eines Punktes', ZNW 59 (1968): 174-209, argues for this option and it has the support of Hengel, 'Prologue', 275.

9 Another oútos ('this one'), as at the start of John 1:2 would have helped.

10 Bultmann's efforts, however, show that he saw the difficulties of John 1:4, difficulties which have often been overlooked subsequently. 
Logos'; it has its being 'in the Logos'. ${ }^{11}$ On this understanding a new thought is introduced here. Why introduce a new thought about the role of the Logos in creation at this point? In the first instance re-expression of an old point seems more likely than introduction of a new point.

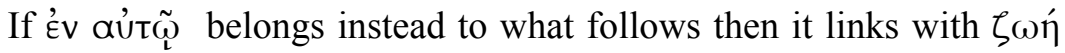
and it is the aliveness of its existence that is immediately dependent on the link with the Logos. ${ }^{12}$ Though it is probably the locative sense for

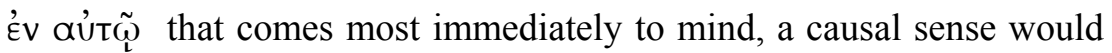

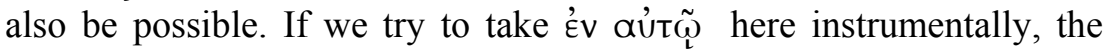
sense for the whole clause is not really distinguishable from an

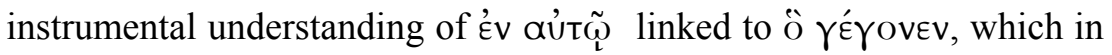
this case would be the more natural link.

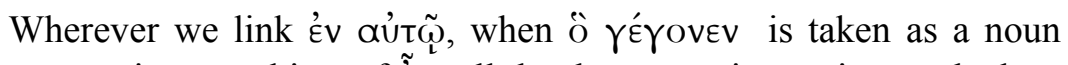
clause serving as subject of $\tilde{\eta} v$, all that has come into existence had, or

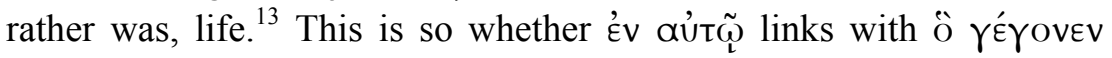
and the thought is as in verse 2, creation through the Logos, or with the same link the $\dot{\varepsilon} v$ is locative, and the existence of the created order is

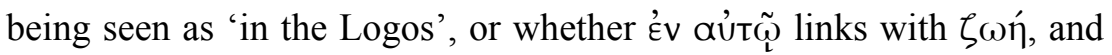
the thought is that creation had life in its connection with or because of the Logos. Does this mean that creation is viewed as alive? Giving a natural sense to the words, it would seem to need to mean this. If this is so there is an interesting focusing of the created order on that which represents life in it. Perhaps the inanimate did not emerge strongly as a category for ancients in the way that it does for us ${ }^{14}$ but, with all allowance for the coining of a striking poetic mode of expression, to

11 Lamarche's approach to the uses of Yivouar in the Johannine Prologue ('Prologue') provides a third option here: 'what has happened in [the Logos] was life', i.e. the ministry of Christ brought life. But on other grounds this approach has already been ruled out.

12 Will the kind of language logic that enables the Pauline correspondence to treat 'in the Spirit' and 'the Spirit in' as interchangeable and 'in Christ' and 'Christ in' as interchangeable apply here as well?

13 If one takes $\zeta \omega \eta$ in John 1:4 as qualitative we might paraphrase as 'what came to be in him had the quality of life' (see Phillips, Prologue, 165). But this should mean that what came to be in the Logos was alive and not simply that within it somewhere (in some of its parts) was life.

14 One could consider the possibility here is that the author is playing with the idea from the philosophers, of order being imposed on the shapeless ú $\lambda \eta$. Life may be being seen as the order that is imposed on the disorderly and shapeless. But this is pure speculation, and does not fit with the strong links to the Genesis creation account, where what has life is sharply distinguished from other parts of the created order. (See further below.) 
say 'all creation is life' remains strained. ${ }^{15}$ But perhaps there are other ways to go.

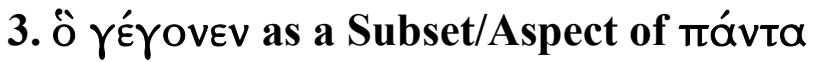

Thus far we have worked with the assumption that 'what has come to be' is the same as 'all things', but there is an alternative. With ô

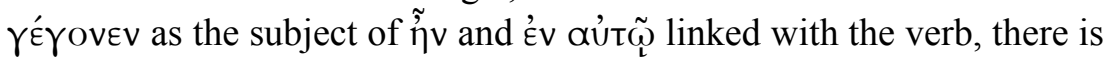
the possibility that 'what has come to be in [the Logos]' in John 1:3-4 is not the same as 'all things' in verse 3, but rather that subset of it which, precisely because it has come to be in the Logos, is alive. ${ }^{16}$ Raymond Brown thinks along these lines. With appeal to Hilary, Ambrose and the older Greek Fathers and on the basis of Greek word order, Brown speaks of 'a narrowing down of creation' here. ${ }^{17}$ The reference, then, would be to that subset of the creation order that has life. Or, perhaps rather we should take the language more immediately literally and speak instead not of a part of creation that has life but of the life that (part of) the creation was privileged to have, and understand that it is the life found in creation that has come to be in the Logos, rather than a part of the creation as such. The Logos is instrumental in all creation, but the life that is found in creation has something more: it has come to be in the Logos. Perhaps we can say it is alive with his life.

15 The difficulty is reflected in the kinds of translations offered. E.g. Beasley-Murray

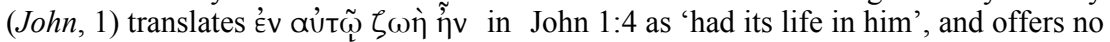
explanation for this departure from the Greek. E. L. Miller (Salvation-History, 17-44,

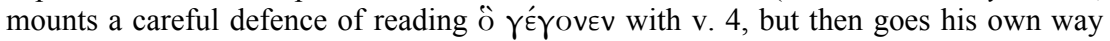
(45-89) in applying this use of the verb not to creation but to the incarnation: 'That which appeared in him was life'. I am not aware of any scholar who has been persuaded that this third use of Yivouat is unrelated to the previous two.

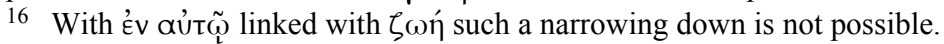

17 R. E. Brown (The Gospel according to John 1-11: A New Translation with Introduction and Commentary [Anchor Bible 29; New York: Doubleday, 1966]: 7). Brown goes on, however, to move away from a creation focus by requiring 'life' in John 1:4 to be 'eternal life' and not 'natural life'. Brown is right that the Gospel writer is ultimately interested in spiritual life, or in Brown's terms 'eternal life' (echoing John's language), but in John 11 it is the restoration of Lazarus' 'natural life' that points to the eternal life that Jesus makes possible. In the Gospel writer's vision of life, there is no dualistic division between natural life and eternal life; he is interested in an aliveness that is comprehensive (e.g. John 10:10), and only eternal because comprehensive. 


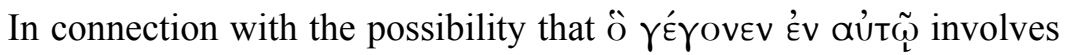
a narrowing down of the focus from all of creation to a part or an aspect of creation, we might consider taking 'life' as a reference to all living creatures. However, despite quite an extensive search I have not been able to document a use of $\zeta \omega \eta$ that matches the English use of 'life' as a collective for 'living creatures' (as in 'All life benefits from the sun'). Such a usage is not found in the $\mathrm{LXX},{ }^{18}$ but is certainly conceivable in the wider Graeco-Roman world. Adam's naming of his wife as Z $\mathbf{\omega}$ in in Genesis 3:20 is focused on her capacity to be lifegiving rather than on her being a living creature. But the usage does suggest that $\zeta \omega \eta$ as a collective for 'all life on the earth' would not be completely out of reach. However, because the plural of $\zeta \tilde{\omega}$ ov ('living being') was readily available to express this thought, to use $\zeta \omega \eta$ instead a writer would need to have wished to express the thought more abstractly for, perhaps, philosophical, religious or poetic reasons. '[All] life forms' is then a possible but not a likely sense for $\zeta \omega \eta$.

Along our present line of thinking, therefore, $\zeta \omega \eta$ in John 1:4 as the life that creatures have (quasi-identified with the blood in OT thought ${ }^{19}$ remains the more likely sense: while all creation has come to be through the Logos, it is the life that is found in creation that has come to be in the Logos.

'Life' in John is characteristically 'eternal life', and John does not elsewhere use the noun of natural life. But he does use the verb in relation to natural life on several occasions. The royal official's son as living is the concern in 4:50, 51, 53. In 11:25-26 the point is made that the prospect of never dying can come via resurrection to the already dead, but is also immediately available to the living who believe in Jesus. In verse $26 \pi \tilde{\alpha} \zeta \dot{\zeta} \zeta \tilde{\omega} v$ is everyone currently alive.

In the Genesis creation account a perspective on life emerges that is likely to sit in the background to what we have in the Johannine prologue which may allow us to specify the sense a little more sharply_given the strong Genesis links of the prologue. Life in Genesis 1 belongs to animate life and not to plant life. The creation of plant life shares a day in Genesis 1:9-13 with the appearance of dry

18 The use of $\gamma \tilde{\eta} \zeta \omega \tilde{\eta} \varsigma$ in Ezek. 26:20; 32:23, 24, 26, 27, 32 for 'land of the living' cannot confidently be claimed for such a usage, as the language imagery might well be חיים 'life' (and adjectivally for 'living') means that the MT cannot provide a guide here.

19 See Gen. 9:4; Lev. 17:11, 14; Deut. 12:23. 
land (where the plant life can grow-no thought is given to marine plant life). The distinctive feature added to the creation by the development of plant life is the potential for self-propagation. This is spoken of in terms of the bearing of seeds. In between plant life and animate life comes the day for the creation of the sun and the moon (vv. 14-19). Then the fifth day (vv. 20-23) is given to the creation of

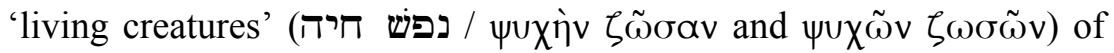
air and sea, which are to be fruitful and to multiply. There is no mention of 'seed' here, though such a way of speaking of animal reproduction was available, as we see in e.g. 3:15. Finally on the sixth day both the land creatures and humanity are created (vv. 24-31). Not a lot is said about the land creatures where they are introduced. They are not said to be 'living creatures'; and they are not blessed and told to be fruitful and multiply. We are no doubt meant to bring these features forward implicitly from their application to the creatures of air and sea. In the case of the link with life, there is a retrospective clarification once humans have been introduced. Humans are identified initially in terms that distinguish them from other animate creation (God-likeness, dominion), but then spoken of in ways that are in parallel with other animate creation (be fruitful and multiply, have plant life for food-in fact, that the creatures of land and air are given plant life for food only emerges in connection with these things' being provided for human food). As well, animal life and human life are bundled together as

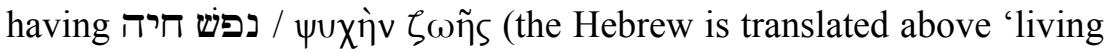
creatures', but 'breath of life' is better here). There is, then, a much sharper division between plant life and animal than between animal life and human. In fact, not only in Genesis but throughout the LXX $\zeta \omega \eta$ is never used of plant life, but only of animal and human life. Life here is animate life, not botanical life. (It fits with this that the life of creatures is said to be in their blood, as does the use of the phrase "breath of life'.) Along this line of thinking then, life in John 1:4 is best taken as referring to the life of animate creatures and not botanical.

Whether we are dealing with all of animate life or the life within animate life, the subset or (probably better) the aspect is distinguished from the whole by describing it as 'what has come to be in the Logos', in contradistinction to the whole which is identified as 'all things [which] came to be through the Logos'. (There is a comparable, but different identification of a subset of 'all things' in the reference to

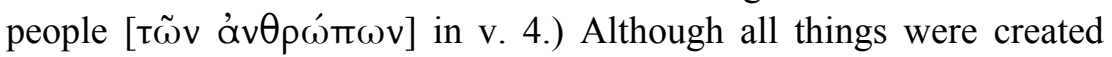


through the Logos, a subset is identified that distinctly has its existence or better its life 'in the Logos', presumably meaning that an abiding link with the Logos keeps living creatures in this distinct form of being, namely that of being alive. Their aliveness is a marker of the link with and therefore the activity of the Logos.

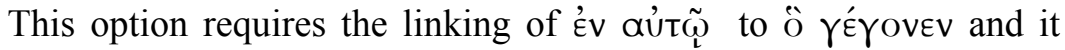
requires '́v $\propto \cup \cup \tilde{\omega}$ to have a sense that is quite distinct from that of $\delta \mathfrak{l}$, au่toũ in verse 3 . At first blush this might seem a serious weakness, but not necessarily so. A sequence involving the creation of 'all through the Logos', 'nothing without the Logos' and 'life in the Logos' is not unattractive artistically. ${ }^{20}$

On this understanding the thought would be that the Logos is involved in all creation, but things that are alive - animate life formshave a more specific link with the Logos, as the fount of their life. ${ }^{21}$ Though not without its own challenges, this approach has the distinct advantage of not needing to speak of all creation as being alive/having life.

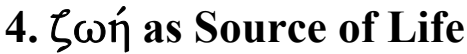

There may, however, be yet another way to go. In John 6:63 we read, 'The words that I have spoken to you are ... life'. The sense is clearly that the words are (potentially) life-giving. Does this open up another line of approach to John 1:3c-4a? Bultmann makes it a fundamental principle of his approach here that 'the passage must speak of the $\zeta \omega \eta$

20 Cf. the comment by W. S. Kurz, 'Intertextual Permutations of the Genesis Word in the Johannine Prologues' in Early Christian Interpretation of the Scriptures of Israel (Sheffield: Sheffield Academic, 1997): 179-90 (esp. 182):

Both Philo and the Johannine prologue are commenting on Genesis, and both are using a 'metaphysics of prepositions' as in emerging Middle Platonism, which stresses different prepositions for different kinds of causality.

Kurz appeals to T. H. Tobin, 'The Prologue of John and Hellenistic Jewish Speculation', $C B Q 52$ (1990): 252-69 (esp. 257-60), who cites Philo, Cher, 125-27, which distinguishes the 'by which', the 'from which', the 'through which' and the 'for which'. I have exercised my own measure of poetic licence in including 'life in the Logos' in the set as I have understood the syntax as requiring 'has come to be in the Logos'. But I suggest that come to be in the Logos (required to mark the narrowing of focus) implies in turn 'life in the Logos'.

21 As already noted for an analogous situation, the thought would be clearer still if the kind of language logic held here that enables the Pauline correspondence to treat both 'in the Spirit' and 'the Spirit in' as interchangeable and 'in Christ' and 'Christ in' as also interchangeable. 
as that power of the Logos that creates life'. ${ }^{22}$ We have had cause to part company with Bultmann over the syntax here, but his observation connects with other important uses of $\zeta \omega \eta$ in John. The Father granting the Son to have life in himself in 5:26 is about the Son being a source of life. 'I am the resurrection and the life' in 11:25 is again a claim about being a source of life. And 'I am the way, the truth and the life' in 14:16 is also clearly about Jesus' capacity for bringing life to others. This is by no means the majority use of 'life' in John, but it is undoubtedly an important use.

This usage would open up the possibility of revisiting the question of whether ô rérovev should be applied only to an aspect or a restricted part of the creation that, according to verse 2 , came into being through the Logos. If 'what has come to be' is said to be lifegiving, this could be claimed of the creation as a whole, as a lifehospitable and life-sustaining place.

At least one dimension of the life-sustaining nature of creation is echoed elsewhere in Johannine thought. John is able to bring the food and drink that Jesus offers into connection with eternal life precisely because food and drink drawn from creation sustain earthly life. In 4:715 Jesus asks for and offers water to drink. He asks for the water that sustains normal human life; and he suggests the appropriateness of asking of him water 'gushing up to eternal life' (v. 15). In 6:27 it is possible that the manna that would spoil sits behind 'the food that perishes'. But whether it does or it does not 'the food that endures for eternal life' implies a contrast between life that perishes and life that is eternal, fed respectively by food that perishes and food that endures. The thought is similar, but differently expressed in verses $31-35$. Jesus points beyond temporarily life-sustaining 'bread' to the permanently life-sustaining 'bread from heaven'. (The language for the effect of what Jesus gives is 'life' in verse 33, but that this is short for 'eternal life' is clear from verse 40 , where the longer form is used. While 'eternal life' in John is life in relationship with God through Jesus [17:3], its connection with life beyond the present one is marked by the language of raising up on the last day in 6:39, 40.) 6:49-51 re-expresses much the same idea, bringing out clearly the limits of manna (the people still died eventually) compared with the living bread that offers life forever. At the end of verse 51 the imagery changes from bread to

22 Bultmann, John, 39 n. 4. 
flesh, and this new focus is developed in verses 52-57. Whatever else is going on, the imagery of eating the flesh and drinking the blood of Jesus here, makes use of the fact that eating and drinking are the two fundamental forms of human ingestion vital for life. The imagery returns to that of bread in verse 58. Finally, in 8:12, Jesus as the light of life is likely to echo the vital role of the light of the sun in nurturing life (evident for example in the connection between the flow of the seasons and the supply of life's needs).

Ought we to be making a distinction here between life-sustaining and life-creating? The Johannine uses surveyed above tend to hover between the two. The vision of eternal life is a continuity of present life transformed into something quite new by its new form of sustenance: now a life of intimate relationship with God and Jesus, and now a life that is secured for eternity. The food and drink comparisons provide images of sustaining life rather than of creating life. On the other hand the birth images in John $(1: 13 ; 3: 3-7)$ are images of the creation of life, or, at least in terms of where the image is coming from in the human sphere, of procreation. ${ }^{23}$ Also relevant here might be the creation account in Genesis, given the various echoes to be found in the תוצא הארץ נפש 1:24 is

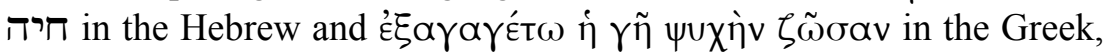
both meaning 'let the earth bring forth living creatures [but the singular is used as a generic collective in both]'. Under God's directive the earth brings forth the creatures of the earth. (The creation of humans is handled separately in vv. 26-27). If only because life-producing is more dramatic than life-sustaining we should probably allow Genesis 1:24 to incline us in the direction of live generation for John $1: 3 \mathrm{c}-4 \mathrm{a}$.

In relation to this new possibility we need to rethink the syntax

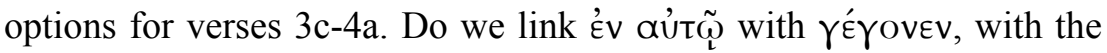
thought as in verse 2, creation through the Logos, or with the same link take $\dot{\varepsilon} v$ as locative, with the existence of the created order being seen as

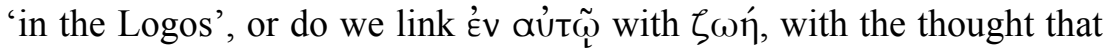
creation was life-giving in its connection with or because of the Logos? In favour of the link with $\gamma^{\prime}$ Yovev is the fact that this gives a threefold

23 John 12:24 is tantalising. What is the role of the earth in the imagery appealed to here? The importance for the application of the 'death' of the seed obscures. But the earth clearly plays a vital role in the generation of the life of the new plant - a matter of no significance for the application of the imagery to the situation of Jesus. 
repetition of a use of yivouar with an attached third person singular pronoun, each pronoun referring to the Logos. Also counting in this direction, and in favour of taking $\mathfrak{E} v$ as instrumental, is the fact that taken this way verses $3 \mathrm{c}-4 \mathrm{a}$ add one new piece of information, "was life-giving', thus allowing for a clear focus as to how the new statement takes us forward from what is already said in verses $3 a-b$. If

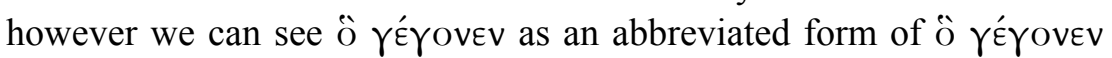

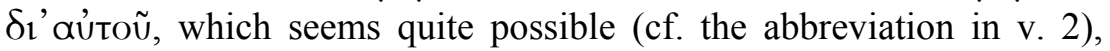

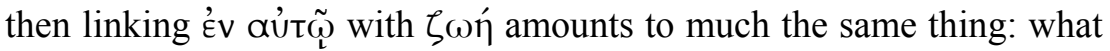
has come to be through the Logos is life-given precisely because of the link with the Logos. This last option has in its favour that by

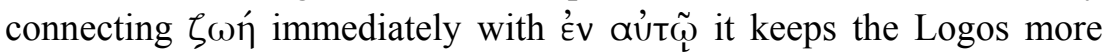
immediately in the frame as we move to the 'life was the light clause' in verse $4 \mathrm{~b}$. (We need a track from 'the life was the light' to the Johannine Jesus' 'I am the light' $[8: 12 ; 9: 5]$. The more readily the life in 1:4 can be seen as an expression or facet of the Logos the easier this transition is.)

\section{Choosing between the Options}

So we have before us two options: either ö Yé Yovev relates to an aspect or dimension of the creation, namely the life within creation - this life exists in the Logos; or ô Y'́rovev is all of creation seen as having a life-giving role for all living creatures, including humans - a role that it has by virtue of its connection with the Logos. We will need to choose between these options on the basis of how successfully they allow the transition to the next clause to work.

'The life was the light' in verse $4 \mathrm{~b}$ is a phrase without parallel in the Gospel or indeed anywhere. I have devoted a separate study to this phrase and must content myself here with quoting from its conclusion.

From our survey of the uses of 'life' and 'light' in the body of the Gospel we have found that the obvious explanation for the total lack of any equivalent in the body of the Gospel to the role of life in John 1:4 is that it is the incarnate life of Jesus as the 'I am' which takes this role. It is Jesus' incarnate life as the light of the world that takes the place given to 'the life' in John 1:4 as 'the light of people'. Given that there is no satisfactory ancient background in terms of which to understand life as light in any cosmic sense, I am led to the conclusion that life as light is a back-formation, designed not so much to draw upon existing patterns of understanding and expression in order to frame the Johannine message 
as to draw upon the pattern created by the incarnation to articulate an understanding of its pre-history in relation to the eternal Logos. ${ }^{24}$

John thinks in terms of a cosmic anticipation of what is to come in its fullness in the incarnate life of Jesus.

We do not have a great deal to do in seeking to determine how John thought that this might have worked. At a general level we can compare the conviction in Romans 1:20 that, 'Ever since the creation of the world [God's] eternal power and divine nature, invisible though they are, have been understood and seen through the things he has made'. Aspects of the creation point beyond themselves to the Creator. And with a stronger life connection we can turn to Acts 17:27-29, where the lifefulness of God is being deduced from the lifefulness of his human 'offspring'. Perhaps we can mark the perennial human fascination with and amazement at the reality of life. ${ }^{25}$ What stands behind this life? We may look for some analogy with the way wisdom is seen as 'a reflection of eternal light' in Wisdom 7:26. In the Gospel of John itself we may find some direction from the way in which restoration of life functions in 4:46-54 and chapter 11, and by comparing 12:9-11. The power of life at work in restoration and resuscitation through Jesus points to the ultimate significance of Jesus and his capacity to bestow eternal life. The signs in John are phenomena in this world. But their significance as signs is their capacity to point beyond themselves to some vital facet of the ultimate significance of Jesus. In this context John's attitude to the sacraments is a matter of continuing dispute in Johannine scholarship, but there can be no doubt that John exploits the functioning of the familiar world in a symbolic way to point to realities that transcend the familiar world. In a seminar study on Johannine symbolism John Painter speaks of 'the world as store-house of symbols which can become vehicles of revelation'. ${ }^{26}$ Beyond these clues there is only speculation. And if I am

24 From a yet unpublished article entitled 'What has come to be in [the Logos] was life, and the life was the light of humanity' (John 1:4)'.

25 The Greek of Ps. 8:2 (LXX v. 3) speaks of praise out of the mouth of babes and sucklings. In line with texts that call for praise of God by various elements of creation (Pss. 69:34; 148:3-4), I think this kind of language might represent an indirect call for a human recognition of God's glory, here in the gift of new human life.

26 J. Painter, 'Johannine Symbols: A Case Study in Epistemology', Journal of Theology for Southern Africa 27 (1979): 26-41 (here 32). The importance of Painter's study is recognised by R. A. Culpepper, Anatomy of the Fourth Gospel (Philadelphia: Fortress, 1983): 188. 
right that the clause in John 1:4 is a back-formation based on the role of the incarnate life of Jesus, then we cannot be sure that John had any particular clear concept of how this might have worked.

Which of our options prepares best for what comes in verse $4 \mathrm{~b}$ ? The second option presents us at once with a problem, the seriousness of which will need to be reflected upon. The problem is this. $\zeta \omega \eta$ in verse $4 \mathrm{a}$ is being taken to mean life-giving, having the capacity to give life, but when this $\zeta \omega \eta$ is taken up in verse $4 \mathrm{~b}$ with $\dot{\eta} \zeta \omega \eta$ it is hard not to see the reference as to actual life rather than to the capacity to give life. A construction ad sensum might be possible: "what has come to be in the Logos was life-giving, and the life produced by this life-giving activity was the light for people'. But a stretch is involved. $\dot{\eta} \zeta \omega \eta \dot{~ i n ~}$ verse $4 b$ is resumptive of $\zeta \omega \eta$ in verse $4 a$, so use of $\zeta \omega \eta$ in the same sense is to be expected.

How does our first option fare for making the transition to verse $4 \mathrm{~b}$ ? In a straightforward way $\zeta \omega \eta$ can have the same meaning in verses $4 \mathrm{a}$ and $4 \mathrm{~b}$ : the life in animate life that is possible only because it has come into being in the Logos.

The lurking concern with the first option is not with the transition, but with the narrowed focus said to be necessary for verses $3 \mathrm{c}-4 \mathrm{a}$. It was first introduced above as a way of avoiding a difficulty created for understanding verse $4 \mathrm{a}$ in connection with the normal sense there for $\zeta \omega \eta$ as natural life. An alternative has emerged, one that has its own difficulty in the form of requiring a different sense for $\zeta \omega \eta$ in verses $4 a$ and $4 \mathrm{~b}$, but an alternative nonetheless.

Are there any considerations that might favour a narrowing of focus in verses $3 c-4 a$ ? There are some. First there is the change of verb tense from aorist to perfect. In the previous clause (v. $3 b$ ) the aorist of the first clause in verse $3 \mathrm{a}$ is repeated, but now a change is introduced.

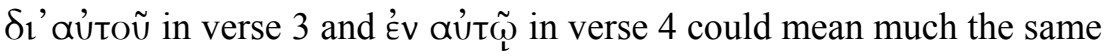
thing. But we have already noted the poetic effectiveness of a sequence involving the creation of 'all through the Logos', 'nothing without the Logos' and 'life in the Logos'. And in this line-up the presence in the middle position of $\chi \omega$ pís ('without'), which certainly cannot have the same meaning as either $\delta 1 \alpha$ or or $\mathfrak{\varepsilon} v$, stands against treating $\varepsilon^{\prime} v$ as virtually synonymous with $\delta \iota^{\prime} .{ }^{27}$

27 Despite its obvious initial attractiveness, equating the force of $\delta \iota^{\prime}$ and $\mathcal{E}^{\prime} v$ in John 1:3-4 is virtually unrepresented in scholarly discussion of the Johannine Prologue. 


\section{Conclusion}

It is probably reasonable to say that the two options remain, but as I evaluate the evidence the case tips in favour of the option which narrows the focus in verses $3 \mathrm{c}-4 \mathrm{a}$ from all of creation to life as a feature of creation. While all things have been created through the Logos life has its existence in the Logos. And because it does it has a unique capacity to point towards the Logos.

It is, then, the life-in-the-Logos of the subset of creation that has life that is identified in verse $4 \mathrm{~b}$ as 'the light' (tò $\varphi \tilde{\omega} \varsigma$ ) for humanity; and the point of this will be the desirability of, by means of the light, making contact with the Logos. Only if paying attention to the life creates a connection with the Logos will it be functioning successfully as light. In one form or another, the connection between the Logos and life is the necessary platform for the thought of John 1:4b. The clearest and most satisfying thought sequence emerges if we distinguish between the role of the Logos in all creation and the closer link of the Logos with that part of creation which is alive. To find the Logos and thence God in creation, the place to focus is on that which is alive or, better, on the life of that which is alive.

By the time we get to John 1:8 the focus on where the light is to be found will have moved: '[John] was not the light'-the incarnation is already being prepared for (cf. the denial language of vv. 20-21). Perhaps we have a pattern of thought that works with a set of concentric circles: creation is the work of the Logos and to that degree testifies to him; more specifically the life in creation acts as light for all people, pointing to the Logos; and most focusedly of all a particular human life will be the light of the world, because he is the Logos become flesh. It is likely that in a more detailed discussion the author might have been prepared to make further subdivision within some of these concentric circles: e.g. it may be that qualitative differences between different exemplars of life in creation would be considered to affect their capacity to function as light. But this is poetry and the author has set down the main parameters for his thought, with a threefold focus: all creation came into being through the Logos; lifeful creation came into being in the Logos; and one unique human life was the Logos.

Working with the assumption that ô Yérovev in John 1:3 belongs with verse 4 is supported to the degree that with such an assumption a 
clear line of thought can be discerned that works within the wider flow of the Johannine prologue. The mystery of animate life, existing as it does 'in the Logos', is seen as shining a light upon humanity, a light intended to illuminate the divine presence in the world in that it reveals the presence and working of the Logos. This shining since the world began will find its more intense counterpart in the Logos become flesh; one human life will become in an ultimate sense the light of the world. 
